\title{
Legal protection of photographs in the digital age: Russian regulation
}

\author{
Marina Rozhkova ${ }^{1,2 *}$, Olga Isaeva ${ }^{3,4}$ \\ ${ }^{1}$ The Institute of Legislation and Comparative Law under the Government of the Russian Federation; Immanuel Kant Baltic Federal \\ University \\ ${ }^{2}$ Cheremushkinskaya street, bldg. 34, 117218, Moscow, Russian Federation; 14 A. Nevskogo ul., Kaliningrad, 236041, Russian \\ Federation, rozhkova-ma@mail.ru \\ ${ }^{3}$ The Institute of Legislation and Comparative Law under the Government of the Russian Federation \\ ${ }^{4}$ Cheremushkinskaya street, bldg. 34, 117218, Moscow, Russian Federation, ol.v.isaeva@ya.ru
}

\begin{abstract}
Appeared in 1826, the photography has been much developed so far. Being mostly used for pragmatic purposes at the dawn of its existence, today, the photography is not only art, but also serves to depict a person at a certain point in time and even for personal identification. The photographs are used as evidence and as technical means of reproduction of other works of authorship. However, although the photographs have always been tacitly divided into informative and aesthetic ones, and various legal regimes of photography have already been enshrined in the Russian legislation, it is still not really clear how all those regimes relate to each other. Trying to answer that question the authors reveal problems and gaps existing in the current Russian regulation of photographs and make some proposals that could be useful for both the scientists when furthering the discussion on the topic and the legislator when developing the existing rules.
\end{abstract}

\section{Introduction}

The world's first photographic images are believed to have been taken in 1822 by Joseph Nicéphore Niépce. Having become fascinated with the chemical fixing of light images and trying to improve the printing method of lithography, the French inventor succeeded in reproducing drawings on pewter plates and lithographic stones by the aid of the sun. The photographic process was called heliography (in French, héliographie), or literally "sun writing". The most famous heliograph of Nicéphore Niépce called "View from the Window at Le Gras", which appeared in 1826, is thought to be the first life photo. Although the heliography was found hardly suitable for life photography, it was widely used by bookmakers when making inserts with pictorial reproductions.

Later, aiming to proceed with experiments on fixing of light images, Nicéphore Niépce became associated with Louis Jacques Mandé Daguerre, who, after Niépce's death, established the art of photography on a practical basis. Daguerre developed the daguerreotype (in French, daguerréotype), a new means of the image reproduction based on the light sensitivity of silver iodide. January 7, 1839, the day when the French Academy of Sciences announced the invention of the daguerreotype, is considered as the day of the photography invention. On June 14, 1839, having provided Daguerre with a lifetime pension, the French Government bought the rights to the process and gave it freely to the world, except England where the process was patented (Patent No. 8194: 'A New or Improved Method for Obtaining the Spontaneous Reproduction of All Images Received in the Focus of the Camera Obscura') [1]. It is worth mentioning that the daguerreotype was not used for a long time: in the second half of the 19th century, it was replaced by other photographic technologies that were easier and cheaper in their use.

It is also worthy of note that at the beginning of its existence and almost until the end of the 19th century, neither the photography was considered as art, nor the creators were considered as authors through whose creative effort the works had been created. The photography was used exclusively for pragmatic purposes: as a means of fixation for the purposes of research, as a technique for documenting events and different items, as an auxiliary (training) tool for artists, etc. Thus, the photography became of particular importance for law enforcement purposes and for the development of forensics which led to the creation of photo identification.

Herewith, the photography was found to be commercially useful. Being an affordable alternative to canvas created by artists, photographs became collectible items: many companies produced small-format photos of celebrities, landscapes from distant places, architectural monuments, and genre scenes. That was when the first photographic albums appeared, when group and

\footnotetext{
* Corresponding author: rozhkova-ma@mail.ru
} 
individual portrait photographs became extremely popular, and when advertising photo cards were created.

At the same time, photographs were not exhibited as works of art. They were exhibited either along with lithographs, or as demonstrations of photographic documentation in science sections, or separately, being presented as examples of an independent field of activity meant to be neither technical nor artistic [2]. It was only at the end of the 19th century that the photography started seriously pretending to be a result of creative activity. That time, the creators of artistic photographs began to use special shooting and printing techniques, e.g.: to apply filters and special lenses, to process the picture print using chemical compounds in order to obtain a more expressive artistic effect, to create compositions using photomontage, etc. As a result, in 1908, the photography received protection under the Bern Convention.

\section{Problem Statement}

The photographs have always been divided into information ("report" ones that fix certain information) and aesthetic photos (reflecting the artistic perception of the author, the photographer). Due to that fact, it is not surprising that some publications, if not court decisions, intuitively disagree with the statutory thesis stating that every photograph shall be deemed a result of intellectual activity. In this context, the position of minimum standards for the protection of works of authorship, which has been developed in the German law, contain valuable insights.

Among the conditions excluding the creativity of a work the German theory of creativity specifies the extent to which the author is able to create an original work of authorship and the mechanical or random nature of the author's actions when creating the item resembling a work of authorship. To the extent that the form of a work is determined by factors, which restrict significantly the author's ability to express their personality in their work, the latter cannot be deemed an original work of authorship even though it is inherently new. In this context, the lack of opportunities for the author to create an original work of authorship precludes the creative nature of their work. In other words, the German copyright does not protect every intellectual item resembling a work of authorship by its outward signs; the German copyright protects only the items of a certain quality allowing to ascertain a close connection with the personality of the author [3].

To wit, according to the German doctrine, the photographs of a "report" (informational, technical) nature - e.g. photographs of a conference participants or those of a board of directors, lookalike photos of tourist attractions, portrait ID photographs, paparazzi photos depicting private lives of stars, etc. - won't be deemed intellectual property items and won't therefore acquire the corresponding legal protection. However, the photographs reflecting the personal touch of the author will undoubtedly be recognized as the copyrighted works. Although it is difficult to define clear criteria for drawing a line between aesthetic and informative photos, these types of photographs are actually very different that becomes particularly obvious at authorial photo exhibitions.

The approach developed in the German law is fully consistent with Directive 2006/116/EC of the European Parliament and of the Council of 12 December 2006 on the term of protection of copyright and certain related rights stating that "[a] photographic work within the meaning of the Berne Convention is to be considered original if it is the author's own intellectual creation reflecting his personality..." (recital 16 in the preamble to Directive 2006/116/EC). Moreover, as the European Court of Justice explained, the author of a photographic work is able to express his "personality" in several ways and at various points of its production: when choosing the subject's pose and the lighting (in the preparation phase), or the angle of view and the atmosphere created (when taking a photograph), or choosing a developing technique he wishes to adopt that includes by means of a software [4]. In other words, according to the European approach, a photograph shall be not only aesthetic to be copyrightable but it also shall reflect the personality of its author.

The division of photographs into informative and aesthetic, a significant number of special applications and software allowing to edit photos, the problems related to the protection of privacy in the digital age along with some other issues create the need for developing different approaches in granting legal protection to photographs. So, how do the various legal regimes of photography, which have already been enshrined in the legislation, relate to each other?

\section{Research Questions}

The Russian legislation establishes several legal regimes that may apply to photographs depending on the "nature" of the images.

\subsection{Legal protection of a photograph depicting a person's image at a certain point in time}

According to Article 152.1 of the Civil Code of the Russian Federation (hereinafter referred to as the Russian Civil Code) the notion of the "citizen's depiction" covers, inter alia, photographs, videos, and other works of visual art depicting an individual. On its surface the mentioned article seems to be aimed at resolving the issues arising from the use of copyright objects depicting a person. However, the content of the specified legal regime along with the placement of the provisions at issue into a chapter of the Russian Civil Code taking no credit to copyright shall be deemed indicative of its completely different purpose.

\subsection{Legal protection of photographs considered to be personal data}

The issue of classifying citizens' photographs as personal data and biometrics has been raised for 
discussion both in doctrine and in legal precedents more than once. However, neither unanimity of opinion nor unambiguous understanding of the clarifications given by the competent executive bodies has been reached. This situation shows that there are some uncertainties in the legal regime at issue, and there is no therefore uniform practice in the application of such rules.

\subsection{Legal protection of photographs considered to be works of authorship}

The copyright protection of photographs is seemingly the most general and common legal regime. However, the absence in the Russian legislation of clear criteria for the copyrightability of photographic works not only gives rise to professional discussions on whether it is possible to recognize photographs lacking originality as copyright items, but also leads to the incoherence of the judicial practice. As a result, inherently uncopyrightable photographs tend to be granted copyright protection, while the copyrightability of original photographic works may be called into question.

\subsection{Legal protection of photographs created by means of applications or software}

Amid the expanding capacity of graphic editors and the increasing use of artificial intelligence software, the question arises as to whether the photographic images shall be copyrightable when their originality has been achieved through post-processing rather than through photography itself. Can we even speak of the originality and any kind of legal protection if all the "creativity" belongs to the software?

\subsection{Legal nature of photographs created without any participation of a legal subject}

Generally, the photographs created without any participation of a legal subject have no cultural value and are not therefore deemed copyrightable. At the same time, pictures taken at random may not only be informative (e.g. surveillance photos) but also spectacular (e.g. a snowboarder's shot from the perspective of a camera falling in the snow or a photo "created" by animals or plants). Thus, the legal regime of such photos is worth being thought and talked about.

\section{Purpose of the Study}

In the digital age, the division of photographs into informative (fixing certain information, "report" ones) and aesthetic (creative, reflecting the artistic perception of the author - photographer) is of particular importance. The purpose hereof was to reveal various legal regimes reflecting the specific nature of photographs, that perform both an informational and aesthetic function, and to compare those regimes with each other.

\section{Research Methods}

The research was being carried out through analysing the Russian and the foreign doctrine as well as law enforcement and judicial practices.

\section{Findings}

As it has already been mentioned above, the Russian legislation does not explicitly distinguish between aesthetic and informative photographs. However, the Russian legislation does grant legal protection to photographs in their various capacities prompting suggestions that such a distinction might be tacit.

\subsection{Legal protection of a photograph depicting a person's image at a certain point in time}

The current Civil Code of the Russian Federation contains Article 152.1. titled "Protection of the citizen's depiction".

Before making comments on the said Article, it's worth mentioning that a similar rule existed in the prior legislation. Article 514 of the Civil Code of the Russian Soviet Federative Socialist Republic dated 1964 (the RSFSR Civil Code) stated the following:

The publication, reproduction and sharing of works of visual art bearing the depiction of an individual shall be admissible only subject to their consent or, after the individual's death, subject to the consent of their children and the live spouse. Such consent is not required in cases when the said is done in the state or public interests, or when the depicted individual sat for the depiction for a payment.

That Article was included into Section IV titled "Copyright" and was supposed to deal with the issues specified in its title: "Protection of interests of the citizen depicted on the works of visual art". That means the said Article settled a problem arising when a work (a copyrighted item) was to be reproduced and shared.

Herewith, Article 152.1 of the Russian Civil Code has nothing to do with the copyright, but it is essentially focused on three objectives at a time.

First and foremost, the Article under consideration sets out the rules for the publication and further use of a citizen's images (photographs, videos, and other works of visual art) depicting an individual at a certain point in time. Since Article 152.1 of the Russian Civil Code expressly states that a depicted person has the right to authorize another person to use their image, we can say that a citizen is granted a legal possibility to dispose of the right to their image whether for free or against payment. In other words, the point at issue is the introduction of the right to a citizen's depiction into commercial turnover.

Second, whereas Article 152.1 of the Russian Civil Code is placed into the chapter on intangible goods, the Article may be considered as being aimed at limiting the intrusion on a person's privacy. The inviolability of private life of a citizen may be violated, inter alia, by 
means of publication of their photographs even if such depictions do not discredit honor and dignity of the depicted person but do report on their private (personal) or family life. This further justifies the set requirement to obtain the consent of the depicted person to use their image and, where appropriate, the consent of other persons explicitly named by the law.

Finally, the provisions of Article 152.1 of the Russian Civil Code establish a legal framework for the exercise of the right to appearance (physical appearance), which the doctrine traditionally considers only within the scope of inalienable rights as being vested in that person by virtue of birth [5]. The widespread practice of photo shooting (when a model gets paid for being depicted) makes the exercise of the right to appearance possible. For the purpose of the foregoing, it is noteworthy that the model may dispose of the right to the resulting photographic image, i.e. give their consent to its publication or any other use. The point is that the law does not provide for a rule allowing the model to revoke the given consent while the jurisprudence recognises the legality of using the images without any prior consent of the model provided that the fact of sitting for payment is proven by relevant evidence [6].

Curiously, foreign legal systems provide for different approaches to the latter issue. For instance, being a model and a TV presenter, an actress was judged by the French Supreme Court (Cour de Cassation) to have no right to preclude the publication of her nude photo, which had been taken by a famous photographer, in an art book, because when she had consented to be photographed, she had also consented to the further publication and exhibition of the photo for any purpose (no. 06-10.305, 2007). At the same time, according to Article 97 of the Italian Copyright Act (Law No. 633 of April 22, 1941), the consent of the portrayed person shall not necessarily be obtained when the portrait is being reproduced for scientific, didactic, or cultural reasons, but neither display nor commercial distribution is permitted when it would prejudice the honour, reputation or dignity of the portrayed person.

\subsection{Legal protection of photographs considered to be personal data}

When Russia acceded to the Council of Europe Convention for the Protection of Individuals with regard to Automatic Processing of Personal Data (ETS No. 108) dated 1981 (hereinafter referred to as Convention 108), which aimed at solving the problems caused by the use of new technologies and ensuring fundamental human rights when the information is being automatically processed, it led to the adoption of the Federal Law of July 27, 2006, No. 152-FZ on Personal Data (hereinafter referred to as the Law on Personal Data). The said law reflects most provision of Convention 108 and, as it is stated in its Article 2, aims at providing for the protection of the rights and liberties of person and citizen in the processing of their personal data, including protection of the rights to the inviolability of private life, personal and family secrets.

Article 11(1) of the Law on Personal Data sets out the concept of biometric personal data, which are defined as "[the] information which characterizes the physiological and biological features of a single individual whereby he/she can be identified (biometric personal data) and is used by an operator to identify a personal data subject". In light of this definition, lawyers generally classify photographs as biometric personal data [7], [8]. However, they do not take into account that not every photo of a citizen is suitable for biometrics.

A review of technical standards in force affords grounds to state that biometrical personal data would cover the photograph which contains distinctive biometric features allowing to recognise the depicted person. In other words, a photographic image of a citizen could be deemed biometric personal data provided that it meets certain requirements (related to lighting, head position, camera location, image resolution, colour saturation, etc. as specified in GOST R ISO/IEC 197945-2013 [9]) and is processed in order to identify the personal data subject. The photographs collected with no identification purposes and used only to confirm certain actions shall not be considered as biometrics.

Accordingly, it is necessary to mention the Federal Service for Supervision of Communications, Information Technology, and Mass Media (Roskomnadzor) explicitly stating in its Clarifications [10] that biometric personal data cover, inter alia, a colour digital photographic image of a person in a foreign passport, photographs of employees or visitors of state and municipal bodies and enterprises (organisations) contained in their access control system (ACS). At the same time, it is noted that photographs of the employees in their personal files shall not be deemed personal data of the employees.

This raises the following question: shall a photographic image of a person, which does not fall under the category of biometric personal data, be deemed personal data? The provisions of Article 3(1) of the Law on Personal Data defining personal data as "any information directly or indirectly concerning an individual who is defined or is being defined (personal data subject)" seem to answer in the affirmative. However, this view is shared only by some lawyers [11], [12]. Speaking of photographs, others classify them into biometric personal data and a citizen's depictions to be protected under the abovementioned Article 152.1 of the Russian Civil Code [13].

In our opinion, the answer to this question should be based on the general premise of the Law on Personal Data specifying that any information, including photographs, could be deemed personal data if it is processed in order to identify a person. Such an approach corresponds to the European legislation [14]. Therefore, a photo of a citizen, which is not to be deemed biometric personal data under Article 3(1) of the Law on Personal Data, may be deemed personal data, because it contains subjective information on the person enabling their identification (recognition), and sometimes, it also contains other additional data, e.g. date and time of the shooting, the camera settings, GPS location, etc. 
However, in cases when the photograph of a citizen is processed for other purposes having nothing to do with their identification, we shall talk about a normal use of a photograph falling under the scope of the abovementioned Article 152.1 of the Russian Civil Code.

\subsection{Legal protection of photographs considered to be works of authorship}

According to Article 1259(1) of the Russian Civil Code, photographic works and works created by means analogous to photography shall be deemed copyrighted items. However, the Russian Civil Code specifies only two requirements for works (including photographic ones) to be copyrightable: a work shall be created by some creative activity of its author (Article 1257) and be expressed in any objective form (Article 1259(3)).

Thus, the Russian legislation only sets out requirements to the creation process (the work creation activity shall be creative) and establishes no requirement (apart from objective form) to the result of such activity. This fact has been recognized by the Court for Intellectual Property Rights stating in its Ruling No.C01664/2017 [15] the following:

The current legislation does not establish special conditions that would be necessary to recognise photographic works to be copyrightable; therefore, the author (photographer) shall enjoy the copyright to any work (photograph) by virtue of the very fact of its creation and regardless of its artistic value and importance.

Herewith, the Supreme Court of the Russian Federation has further developed that idea explaining that: “...the mere lack of novelty, uniqueness and (or) originality of the intellectual product cannot point to the fact that such a product is not a result of creative activity and is not therefore a copyrighted item" [16].

The approach, according to which any photograph shall be deemed copyrightable regardless of its originality and artistic value, can hardly be considered correct. Pursuing that approach would mean that a legal protection to be granted to a "work of authorship" shall be granted to any photograph even deprived of originality and individuality: e.g. lookalike photos of tourist attractions taken at the same angle [17], [18], photos of products offered for sale [19], [20], portrait ID photographs, "report" photos taken during any meeting or even occurrence [21], etc.

As it has already been discussed above, the European legislation is developing in a different way following the approach, according to which a photograph would be deemed a work of authorship provided that it is original and reflects the personality of its author. In our opinion, such an approach shall be adopted by the Russian legislation: the originality should become a requirement for the copyrightability of works. As for photographs, a photo should be deemed original if it is possible to characterize it as reflecting the personal touch of the author and being, in any case, distinctive from others. The said may be achieved through a specific style or a shooting technique or angle, by presence of a distinctive element on the picture, by choosing a time for shooting and the composition of elements, etc.

In furtherance of the foregoing, a due regard should be given to the question of whether the photograph of a work of authorship (e.g. a photo of a picture or of a sculpture in a gallery) shall be deemed a derivative work (an alteration of another work) [22] or a reproduction of that work by means of photography [23]. In our opinion, a simple fixation of a work of authorship by any means, including both videorecording and photography, shall be deemed a reproduction of that work, which is a way to use the work (Article 1270(2) of the Russian Civil Code) and is therefore subject to the consent of its author. In such cases, a photograph is usually no more than a simple technical means for reproduction and may not be generally deemed a copyrightable item.

At the same time, when someone else's work of authorship has been photographed by accident or is just a background, such a photograph can easily be deemed an original work of a derivative nature, which can be created only subject to the consent of the author (right holder) of the work used for its creation (Article 1260(3) of the Russian Civil Code).

\subsection{Legal protection of photographs created by means of applications or software}

Within the context of the originality of photographs, the question arises as to whether a photographic image might be considered a work of authorship if its efficiency has been achieved through a competent use of the predefined functions of Photoshop or another graphic editor, rather than through the creativity of its author. This question becomes particularly relevant in response to the ever-increasing use of programmes taking advantages of artificial intelligence.

On the one hand, today, the artificial intelligence is involved in both the process of taking photos by means of smartphones and the process of editing photos. Technologies in general, and artificial intelligence in particular make it possible to edit photographs without much intellectual effort: it is enough to upload a photo and to indicate what needs to be changed (the style of the photo, the composition, the white balance, etc.), to use automatic correction, or to choose a style of a famous painter (as Prizma suggests for instance) in order to get a completely different photo. However, it is difficult to believe that the originality of the image achieved through such editing may be considered as reflecting the personal touch of its author.

On the other hand, some authors can leave their personal touch and express their individuality, their own style and a particular vision of the object being photographed only by using Photoshop or another editor. The mixing of "ordinary" images with unexpected fantasy details, the author's colour correction, an unusual collage of several images, special effects, etc. may "change the reality": the resulting image does usually reflect the ideas that are simply impossible to be brought to life without certain functions of graphic editors. 
Herewith, such editing often requires far more time and intellectual resources than the creation of the original (initial) image itself.

In such a case, it seems to be very reasonable to speak about creating a work of authorship: the author creates a new original image, that reflects their personality, by means of a graphic editor. It is necessary to pay attention to the following point: if such a photographic work has been created basing on another original photo, there are all grounds to point to the creation of a derivative work (Article 1260(1) of the Russian Civil Code) that binds the author of the derivative work to get the consent of the author of the original (initial) work to use the original copyrighted item.

\subsection{Legal nature of photographs created without any participation of a legal subject}

The photographs created without any participation of a legal subject can be conveniently classified into those created automatically and created by accident due to some external (natural) factors.

The first group includes photographs taken by redlight-running cameras or in automatic mode, e.g. by outdoor cameras [24]. The photographs obtained in this way cannot be subject to copyright protection not only due to the lack of creativity but also due to the absence of the legal subject. However, such photographs are commonly used as evidence when it's necessary to establish whether an act has been committed, including in court proceedings [25], [26], [27].

The second group may include photographs "created" by animals. Since only an individual can be a legal subject, a photograph taken by an animal will not be copyrightable. In other words, neither the owner of the camera, nor the owner of the animal will have the copyright to such a photo: the photo shall customarily be considered as a public domain item.

For instance, in a famous case on the copyright to photos taken by a monkey [28], although David Slater (the photographer to whom the camera belonged) tried to justify his copyright by the fact that it had been him who provided conditions under which the creation of the images at issue became possible, the copyright protection was denied [29].

It is also noteworthy that the U.S. Copyright Office has supplemented the Compendium of U.S. Copyright Office Practices with an explicit statement in section 313.2 that the Office would not register works produced by nature, animals, or plants. The first cited example is "a photograph taken by a monkey" [30].

\section{Conclusion}

The study allows concluding that the current Russian legislation provides several regimes for legal protection of photographic images establishing no clear boundaries for each of the regimes. Due to the lack of official explanations by representatives of legal profession, the photographs, which do not seem to be copyrightable, are granted copyright protection, and an ordinary image of a citizen may be covered by two legal regimes at a time. We hope that the problems and the gaps in legal regulation we have outlined, and the proposals we have made would form the basis for further scientific discussion on the topic considered herein.

\section{References}

1. S. Edwards, 'Beard Patentee': Daguerreotype Property and Authorship. Oxford Art Journal 36.3, 369-394 (2013) doi:10.1093/oxartj/kct030

2. V. Levashov, Lectures on the History of Photography (IE Gusev, Moscow, 2014)

3. A.V. Kashanin, Civil Law Review 4, 23-62 (2007)

4. Eva-Maria Painer v. Standard Verlags $\mathrm{GmbH}$ and Others, EU:C:2011:798 (ECJ, 2011)

5. M.A. Rozhkova, Civil Code of the Russian Federation. Article-by-article Commentary on Chapters 6-12 (Statut, Moscow, 2014)

6. Case No. 33-46886, Appellate decision (Moscow City Court, 24.11.2014), URL: https://sudact.ru/regular/doc/GXJJ6aPUNpdR/ (date of access: 11.12.2020)

7. A.V. Dolmatov, E.A. Dolmatov, Vestnik of Saint Petersburg Juridical Academy 3, 53-60 (2018)

8. M.S. Krivogin, Journal of the Higher School of Economics 2, 80-89 (2017) doi: 10.17323/20728166.2017.2.80.89

9. Information technologies. Biometrics. Biometric data interchange formats. Part 5. Face image data. (2015). GOST R ISO/IEC 19794-5-2013 from January 1, 2015 (Standartinform, Moscow, 2015)

10. Federal Service for Supervision of Communications, Information Technology, and Mass Media. Clarifications regarding the consideration of photo, video, fingerprint and other information as biometric personal data and the peculiarities of their processing (September 2, 2013) (Moscow, 2013)

11. M.S. Krivogin, Proceedings of Voronezh State University. Series: Law 1, 108-117 (2018)

12. M.G. Moshkovich, Glavkniga 21, 74-78 (2018)

13. D.R. Galiullina, Archive. History. Present 15, 264268 (2015)

14. Determining what is personal data. Data Protection Act, URL: $\quad$ https://ico.org.uk/media/fororganisations/documents/1554/determining-whatis-personal-data.pdf (date of access: 11.12.2020)

15. Case No. A57-29754/2016, Ruling No. C01664/2017 (Court for Intellectual Property Rights, 30.10.2017), URL: https://kad.arbitr.ru/Card/1 ecal cbb-8902-41d4b955-03b6b42d8f72 (date of access: 11.12.2020)

16. Resolution No. 10 On Application of Part Four of the Civil Code of the Russian Federation (Plenum 
of the Supreme Court of the Russian Federation, 23.04.2019)

17. Case No. A40-239418/2016, Ruling No. C01812/2017 (Court for Intellectual Property Rights, 30.10.2017), URL: https://kad.arbitr.ru/Card/57f25041-f56b-4d949d42-29ffc866d13a (date of access: 11.12.2020)

18. Case No. A60-47992/2017, Ruling No. 309-ЭC194080 (Supreme Court of the Russian Federation, 19.04.2019), URL: https://sudact.ru/vsrf/doc/liCZ7K9swuQr/ (date of access: 11.12.2020)

19. Case No. 33-881, Appellate Decision (Moscow City Court, 28.01.2019), URL: https://www.mosgorsud.ru/mgs/services/cases/appealcivil/details/e4264e40-5c3c-4a90-83bc9f58f35fabde?caseNumber $=33-881 / 2019$ (date of access: 11.12 .2020 )

20. Case No. A50-29320/2015, Ruling No. 309-ЭC174997 (Supreme Court of the Russian Federation, 26.06.2017), URL: https://sudact.ru/vsrf/doc/Dk3pDXuMNWmZ/ (date of access: 11.12.2020)

21. Case No. A49-6557/2015, Ruling No. 306-ЭC1611177 (Supreme Court of the Russian Federation, 19.08.2016), URL: https://sudact.ru/vsrf/doc/eDuTe8iTtPNv/ (date of access: 11.12.2020)

22. A. Dovgalyuk, Zakon.ru, (2015) URL: https://zakon.ru/blog/2015/05/08/fotografiya kak o bekt avtorskix prav chast 3 (date of access: 11.12.2020)

23. A. Dovgalyuk, Zakon.ru, (2015) URL: https://zakon.ru/blog/2015/5/7/fotografiya kak obe kt avtorskix prav chast 2 (date of access: 11.12.2020)

24. E.T. Sidorov, D.A. Temnyakov, Bulletin of the Economic Security 1, 230-238 (2016)

25. Case No. 46-АД 18-15, Ruling (Supreme Court of the Russian Federation, 10.09.2018), URL: https://sudact.ru/vsrf/doc/10iO7GAbMrHG/ (date of access: 11.12.2020)

26. Case No. 57-АД19-42, Ruling (Supreme Court of the Russian Federation, 09.08.2019), URL: https://sudact.ru/vsrf/doc/RWJcweP00md4/ (date of access: 11.12 .2020$)$

27. Case No. 78-АД20-1, Ruling (Supreme Court of the Russian Federation, 18.03.2020), URL: https://sudact.ru/vsrf/doc/ka42Yxy7eXH8/ (date of access: 11.12.2020)

28. Naruto v. Slater, 888 F.3d 418 (2018)

29. A. Guadamuz, Internet Policy Review 5 (2016), doi: $10.14763 / 2016.1 .398$

30. I. Bardov, Which photographs shall be considered as copyrighted items? (2017), URL: https://bardov.legal/qanda/kakie-fotografiiyavlyayutsya-obektami-avtorskogo-prava (date of access: 11.12 .2020 ) 